ISLAMIC BANKING: Jurnal Pemikiran dan Pengembangan Perbankan Syariah, Volume 7 Nomor 1 Edisi Agustus 2021 | 1

\title{
THE ROLE OF THE STATE IN THE ISLAMIC ECONOMIC SYSTEM: A REVIEW OF ABBAS MIRAKHOR'S THOUGHT
}

\author{
Havis Aravik \\ Sekolah Tinggi Ekonomi dan Bisnis Syariah (STEBIS) Indo Global Mandiri Palembang \\ Email: havis@stebisigm.ac.id
}

Achmad Irwan Hamzani

Universitas Pancasakti, Tegal

Email: al_hamzani@upstegal.ac.id

Nur Khasanah

IAIN Pekalongan

Email: nur.khasanah@iainpekalongan.ac.id

\begin{abstract}
Islamic economy is a progressive and dynamic economy. Various new theories have been raised as an offer for the development of Islamic economics, one of which was carried out by Abbas Mirakhor. This article discusses the main principles of the economic system to the role of the state; an offer of Abbas Mirakhor to Islamic economics. To know more deeply the Islamic economic thoughts offered by Abbas Mirakhor, from the main principles of the economic system to the role of the state in the economy. This article uses a type of qualitative research using library research. The results of this study indicate that Abbas is a practitioner of Islamic economics and finance who has a good reputation in the world, both Islam and the West and is considered a reformer in the Islamic economy, and is part of the Iqtishad school of thought. In the field of the Islamic economic system, Mirakhor argues that the main principle of the Islamic economic system requires distribution in two mechanisms, namely freedom, and justice, without which prosperity will not be realized. Therefore, there is a need for a hermeneutical approach to answering various problems that occur in the Islamic economic system. In the context of the state, according to Mirakhor, the state has a very significant role in the welfare of society, especially through its productive policies. The state must also be present in realizing justice amid society.
\end{abstract}

Keywords: Abbas Mirakhor, Islamic Economic System, Role of the State

\begin{abstract}
Abstrak
Ekonomi Islam merupakan ekonomi progresif dan dinamis. Berbagai teori-teori baru dimunculkan sebagai tawaran terhadap perkembangan ekonomi Islam, salah satunya yang dilakukan Abbas Mirakhor. Artikel ini membahas tentangdari prinsip utama sistem ekonomi sampai peran negara; sebuah tawaran Abbas Mirakhor terhadap ekonomi Islam. Dengan tujuan untuk mengetahui lebih mendalam pemikiran-pemikiran ekonomi Islam yang ditawarkan Abbas Mirakhor baik dari prinsip utama sistem ekonomi sampai peran negara dalam ekonomi. Artikel
\end{abstract}




\section{Havis Aravik, Achmad Irwan Hamzani, Nur Khasanah, THE ROLE OF THE STATE IN ............}

ini menggunakan jenis penelitian kualitatif yang menggunakan penelitian kepustakaan. Hasil penelitian ini memperlihatkan bahwa Abbas praktisi ekonomi dan keuangan Islam yang memiliki reputasi baik di dunia, baik Islam maupun Barat dan dianggap sebagai salah satu pembaharu dalam ekonomi Islam serta tergabung dalam madzhab Iqtishad. Dalam bidang sistem ekonomi Islam, Mirakhor berpendapat bahwa prinsip utama system ekonomi Islam menghendaki terjadinya pendistribusian dalam dua mekanisme, yakni kebebasan dan keadilan, tanpa itu tidak akan terwujud kesejahteraan. Oleh karenanya, perlunya pendekatan hermenuetik untuk menjawab berbagai permasalahan-permasalahan yang terjadi dalam sistem ekonomi Islam. Dalam kontek negara, menurut Mirakhor, negara memiliki peran yang sangat signifikan terhadap kesejahteraan masyarakat terutama lewat kebijakan-kebijakan produktif yang dikeluarkannya. Negara juga harus hadir dalam mewujudkan keadilan di tengah-tengah masyarakat.

Kata Kunci : Abbas Mirakhor, Sistem Ekonomi Islam, Peran Negara

\section{Introduction}

Islamic economy is one of the world economic systems. Its existence is parallel to other world economies such as capitalist and socialist economies. Although there are many fundamental differences in it. With an orientation towards maslahah and falah, Islamic economics is at the forefront of offering various economic concepts that are non-discriminatory, detrimental, and exploitative. At this point, the Islamic economy is frontier and more advanced than the two existing economic systems.

Since its inception, Islamic economics has been widely doubted, even considered to be baseless and not based on scientific facts and methodology, especially among Western scientists and economists. They do not believe in the ability of Islamic economics to answer various problems that arise in the economic field. Therefore, it is not surprising that the contribution of economic thought is ignored by Western scientists and economists, especially in world economics textbooks.

Yet when viewed from the historical aspect, Islamic economics has been discussed and practiced in everyday life. Even since the time of the Prophet Muhammad and his friends. However, the development of Islamic economics stopped, because of the dichotomy between religion and science which was born as a result of dogmatization that occurred during the dark period (taqlid). In addition, the strong domination of the capitalist and socialist economy as a result of the politics of 
Imperialism and Colonialism contributed to the Islamic economy being increasingly neglected and marginalized (Aravik, 2017).

Islamic economics began to be a serious study back in the 1930s with the birth of progressive and dynamic Islamic economic thoughts that we're able to answer various fundamental problems in the economic field. One of the important figures in the field of economic studies is Abbas Mirakhor, who offers many Islamic economic concepts ranging from the main principles of the Islamic economic system to the role of the state in realizing people's welfare.

\section{Research Methode}

This research is a type of qualitative research that uses a library research method. Library research is research conducted using literature, either in the form of books, notes, or other reference sources. Data collection techniques in this study are identification of discourse through books, articles, journals, web (internet), and other information related to the title of the research to look for things related to the theme discussed. This research uses data analysis in the form of content analysis. This method is used to analyze the meaning contained in Abbas Mirakhor's thoughts on Islamic economics. The resulting data is descriptive data that is written words presented narratively.

\section{Result and Discussion}

\section{A. Biography of Abbas Mirakhor}

Mirakhor is a practitioner of Islamic economics and finance who has a good reputation in the world, both Islam and the West, and is even considered one of the reformers of the world's Islamic economy, who is credible and consistent in building Islamic economic scientific discourses. With the Alquran and Sunnah and sources of fiqh as analysis tools. Markhor formulated the ideal Islamic economic concept. From there, Mirakhor found that Islam as a religion of rahmatan lil alamin, never separated between the profane and the sacred. With Tauhid as the foundation of economic and 


\section{4 | Havis Aravik, Achmad Irwan Hamzani, Nur Khasanah, THE ROLE OF THE STATE IN ............}

financial activities, Mirakhor believes that Islamic economics is the solution to various contemporary economic problems.

Born in Iran. Obtained Masters and Ph.D. degrees in economics at Kansas State University in the United States. In 1968, Mirakhor began his academic career at the University of Alabama, USA. In 1984, he joined the IMF in Washington DC as an economist. He spent 24 years with the IMF, served as Executive Director of the organization and Dean of the Executive Board, retiring in 2008. From 2010 until now he has joined INCEIF (International Center for Education in Islamic Finance Malaysia).

Mirakhor is one of the important figures of the Iqtishaduna school which was pioneered by Muhammad Baqir Al-Sadr, the author of the book Iqtishaduna. This school argues that studying economics must be seen from two aspects, namely the philosophy of economics or normative economics and positive economics. An example of positive economics is studying the theory of consumption and demand which is a general phenomenon and can be accepted by anyone without being influenced by ideology. Meanwhile, from the aspect of the philosophy of economics which is the result of human thought, it will be found that each group of people has an ideology, a different perspective. For example, it concerns the discussion of 'justice'.

According to the concept of classical capitalism what is meant by "fair" is you get what you deserved means "you get what you have worked for". Meanwhile, according to the classical socialism group translating the meaning of "fair", namely no one has the privilege to get more than others, meaning that no one gets the facility to get more than others, in other words, that everyone gets equal. But Islam has its meaning in interpreting 'fair', namely laa tadhlimuuna wa laa tudhlamuuna which means not judging one another (Aravik, 2017).

So according to the Iqtishaduna School of thought that there is a difference in principle between economics and Islamic ideology so that there will not be a meeting point between Islam and economics. So economics cannot go in harmony with Islam. Economics is still economics, and Islam is still Islam. These two things will not be reconciled because they come from different understandings and philosophies. One is not-Islam (don't believe in God) and one is Muslim (God). This difference in 
understanding and philosophy will have an impact on the different perspectives used in viewing an economic problem, including the analytical tools used.

In addition, this school argues that problems in the economy arise because of an unequal and unfair distribution as a result of an economic system that justifies the exploitation of a group of weak parties by a group of strong parties, where the strong will be able to control the resources that are while on the other hand, the weak have no access to these resources. So that economic problems arise not because of limited resources, but because of unlimited human greed. In addition, in Islam it has been affirmed that Allah Swt.. has created creatures in this world including humans with sufficient economic resources as confirmed in His words "And $\mathrm{He}$ has created everything and He determines its measurements as neatly as possible" (QS. al-Furqan [25]: 2). Thus, Allah Swt. has created everything that is perfectly measurable. This means that Allah Swt. has provided sufficient resources for humans. So in this case the concept of scarcity is unacceptable (Aravik, 2020).

This school also rejects the notion that human needs are unlimited. Because, in certain needs such as eating and drinking when the stomach is full, then he is satisfied because his needs have been met. So that the conclusion, that human needs are not limited as described in the concept of the law of diminishing marginal utility that the more goods are consumed, at a certain point it will cause additional satisfaction from each additional quantity of goods consumed will decrease.

With the various problems above, the term Islamic economics according to this School is an inaccurate and misleading term, so that the term Islamic economics must be stopped and eliminated. Instead, to explain the economic system with Islamic principles, a new term originating from Islamic philosophy is offered, namely Iqtishad. Iqtishad according to this School is not just a translation of economics. Iqtishad comes from Arabic qasd which means equilibrium or equal, balanced or intermediate state. All conventional economic theories are rejected and discarded, and replaced by new theories based on the texts of the al-Qur'an and Sunnah. Therefore, compiling and 
6 | Havis Aravik, Achmad Irwan Hamzani, Nur Khasanah, THE ROLE OF THE STATE IN ............

reconstructing separate economics from the al-Qur'an and Sunnah is a must (Aravik, 2017).

\section{B. Abbas Mirakhor's Economic Thought}

Abbas Mirakhor is one of the important figures in the Iqtishad school outside of Baqir al-Sadr, Ali Shariati, and Kadim As-Sadr. Until 2017, Abbas Mirakhor has written 19 books, 17 journals, and 7 papers. Thoughts on Islamic economics can be found in his works such as Introduction to Islamic Economics: Theory and Application (2014), Risk Sharing in Finance: The Islamic Finance Alternative (2011), An Introduction to Islamic Finance: Theory and Practice (2011), The Stability of Islamic Finance: Creating a Resilient Financial Environment for a Secure Future (2010), Globalization \& Islamic Finance: Converge, Prospects \& Challenges (2009), New Issues in Islamic Finance and Economics: Progress and Challenges (2009), An Introduction to Islamic Finance: Theory and Practice (2006), Theoretical Studies in Islamic Banking and Finance (2005), and Theoretical Studies in Islamic Banking and Finance (1988).

Here are some of Abbas Mirakhor's economic thoughts which greatly contributed to the thinking and development of global Islamic economics and finance:

\section{Main Principles of Islamic Economic System}

The Islamic economic system is a collection of institutions, namely formal and informal codes of ethics and their enforcement characteristics, which were designed by shahibut tasyri 'namely Allah Swt. through various regulations described in the Alqur'an, operated by the Sunnah of the Prophet Muhammad and extended to new situations by ijtihad, to handle limited resource allocation, production, exchange of goods and services, and distribution of income and wealth (Iqbal, Zamir; Mirakhor, 2011). The Islamic economic system requires that in terms of distribution it must be based on two aspects, namely freedom, and justice. Freedom here is the freedom that is framed by the values of monotheism and justice, unlike the capitalist understanding which states as an act of freeing humans to act and act without interference from any party, but as a balance between individuals and their material and spiritual elements, the 
balance between individual and society as well as between one society and another (Zakiyah, 2017).

To provide a comprehensive understanding of the Islamic economic system, Mirakhor suggested that the approach in the study of Islamic economics also uses a hermeneutical approach. This approach is different from interpretation because the hermeneutical nature is the process of extracting economic meaning from the first order interpretation. With this approach, it is estimated that Islamic economics in the future will be rich with economic theories that are truly based on the Koran and Sunnah (Mirakhor, 2007). So that it can achieve the goal of Islam as a religion of rahamatan lil alamin (QS. Al-Baqarah [2]: 107), in which it fosters every Muslim to live a good life (QS. Al-Nahl [16]: 97) and live prosperously (QS. al-Hajj [22]: 77), providing convenience and poverty alleviation (QS. al-Baqarah [2]: 185), creating mutual prosperity (QS. al-A'raf [7]: 96, 58), maintaining the climate of love and compassion (QS. Maryam [19]: 97), and ensure freedom from moral corruption (QS. al-Anfal [8]: 73; al-Rum [30]: 41), hunger and fear (QS. al -Nahl [16]: 112; al-Quraysh [106]: 4), and mental tension (QS. al-Ra'd [13]: 28) (Borhan \& Sa'ari, 2002).

Methodologically, Islam has provided general guidelines and principles for economic activities to run following the corridors of humanity (Haneef, 2005). Epistemologically, Islam does not separate the economy from the value system. Islamic teachings are a moral imperative category to control human economic behavior (Wilber, 2003). The main principles of the Islamic economic system are as follows:

First, property rights. The first basic principle of ownership in Islam states that Allah alone is the real owner of the original owner. So that human beings can materially carry out their duties and obligations, they are given the right to have. Therefore, the second principle of ownership forms the collectivity right over the resources a person has. A person can acquire ownership rights to property through his creative work, and/or by transfer by exchange, contract, loan, or inheritance.

Second, the obligation of ownership. Individual responsibility for ownership is the responsibility of sharing income and not wasting, destroying, wasting, or using these 


\section{Havis Aravik, Achmad Irwan Hamzani, Nur Khasanah, THE ROLE OF THE STATE IN ............}

items for purposes that are not permitted by sharia. If the individual has carried out their duty to share, by the manner and amount determined by sharia, and does not violate the rules of the sharia, then the individual's right to property cannot be contested and no one has the right to forcefully ask (or take over) that person's property for others (Iqbal, Zamir; Mirakhor, 2011).

Third, the contract. The concept of contract in Islam is not only important in the legal aspect of exchange, as a necessary institution for the fulfillment of legitimate human needs, but also as a concept that underlies sharia. A Muslim is constantly reminded of the importance of contractual agreements, and believers must honor their covenant with their Lord. One of the reasons why the Islamic muamalah (transaction) system is so clear is that it is based on solid contract principles and is also based on the rights and obligations of each party to the contract.

Fourth, trust. Islam emphasizes trust as a mandatory attribute for everyone. The root word of faith is the same as the root word amanah. Fulfilling the terms of contracts and always keeping promises with other members of society is a concept based on the obligation to be loyal to the original and primordial covenants between humans and Allah Swt. (QS. Al-A'raf [7]: 172), keeping promises and trusts are characteristics of a believer (QS. Al-Mu'minun [23]: 1-8), orders occupy a promise for those who believe and there is accountability in the hereafter (QS. Saba [34]: 17), and trust as the main characteristics of the prophets and apostles (QS. Asy-Syura [42]: 107, 125, 143, 162, 178, and 193) and treason will be condemned (QS. Al-Anfal [8]: 58, Yusuf [12]: 52) (Iqbal, Zamir; Mirakhor, 2011).

Fifth, individual obligations, rights, and self-interest. The obligations, rights, and restrictions defined by sharia must be obeyed if an individual or system is to have an Islamic identity. Individuals have guaranteed natural rights, including the right of individuals to pursue their economic interests. This potential right remains even if the individual is unable to actualize it. On the other hand, if the person is able but does not carry out his obligations, that right is also abolished. In the context of self-interest, sharia justifies individual self-interest, provided that self-interest is in line with spiritual, temporal, and eternal interests. 
Sixth, work. Work is often referred to as al-Amal and al-fi'il. Al-Qur'an upholds work and places it at the level of worship, and considers it an inseparable dimension of faith itself. Conversely, laziness or spending time on unproductive and useless work is considered a sign of a lack of faith and the nature of the unbeliever. Because Islam does not teach class differences, all types of work that are not in conflict with sharia are not low jobs (Iqbal, Zamir; Mirakhor, 2011).

Seventh, wealth. Islam considers wealth as the lifeblood of a community that must continue to rotate. Therefore, the practice of amassing wealth is prohibited. The implication is that wealth can legitimately be invested to increase welfare. Expenditures of wealth is an obligation regulated by sharia. After the obligation is carried out, the remaining property belongs to the owner but must be used following sharia regulations. In addition, Islam regulates wealth to minimize conflict between rich and poor groups, through fair distribution of wealth (Rahman, 2017).

Eighth, blessing. An important factor in the Islamic incentive system is the concept of blessing which serves as a material enticement for individuals to follow justified behavior. The concept of blessing states that correct behavior, namely behavior that is blessed by Allah Swt., will get multiple rewards. The better the behavior, the greater the presence of the blessing. This concept emphasizes that someone who spends his wealth because of Allah, will not cause his wealth to decrease but instead increase. This kind of action will earn the culprit a lot of merits. This concept creates a positive correlation between behavior and system prosperity (Iqbal, Zamir; Mirakhor, 2011).

Ninth, risk-sharing. This is based on the principle of liability, which states that profits are justified based on the responsibility taken by a person, there is even a possibility that each party is also responsible for the losses and consequences that may arise. Tenth, competition, and cooperation. The Islamic economic system does not make humans merely tools in achieving economic or state goals. Islam tries to guide people towards direct and responsible individual action and participation in economic matters using solidarity and cooperation which will result in economic dynamism and growth. 


\section{0 | Havis Aravik, Achmad Irwan Hamzani, Nur Khasanah, THE ROLE OF THE STATE IN ............}

Therefore, Islam uses cooperation and competition in organizing an ideal society through harmonization and reconciliation between two opposing camps. Al-Qur'an and Sunnah clearly state the nature of competition and cooperation, namely humans can work together and compete for good and evil. Al-Qur'an and Sunnah emphasize that competition and cooperation must be used in piety and piety, not evil (QS. Al-Baqarah [2]: 5) (Iqbal, Zamir; Mirakhor, 2011).

The paradigm of the Islamic economic system challenges conventional economic thinking in several fields, including a). Justice and equality are the most important priorities of Islam and its teachings in the economic field. The ideas of justice and equality from production to distribution are rooted in the system. Social justice in Islam contains efforts to create and provide equal opportunities and eliminate various barriers to equity for every member of society. b) the Islamic paradigm includes a spiritual and moral framework that emphasizes the value of human relations rather than mastery of the material. c) the Islamic system creates a balanced relationship between individuals and society. self-interest and individual wealth are not prohibited but are regulated for the advancement of a greater collectivity. d) the individual's pursuit of maximum profit in the firm and maximum satisfaction in consumption is not the sole goal of society and futile consumption is discouraged. e) Recognition and protection of property rights of all members of society is the foundation of society, which is stockholder-oriented, safeguards the rights of all people, and reminds them of their responsibilities (Iqbal, Zamir; Mirakhor, 2011).

\section{The Concept of Economic Justice}

Allah Swt. has created and designed His creation including the universe and its nature, as well as humans in equal proportion. If there is a deviation from this balance, the entire system of beings may collapse or function poorly, including in economic activities carried out by humans (Adnan Abd Rashid \& Arifin Mamat, 2013). Islam states that justice is a universal goal to be achieved in perfect balance (Zakiyah, 2017). Meanwhile, the main goal of Muslims is the creation of economic justice which is part of a just, healthy, and moral society. Islam expects the creation of an energetic, 
ISLAMIC BANKING: Jurnal Pemikiran dan Pengembangan Perbankan Syariah, Volume 7 Nomor 1 Edisi Agustus 2021

purposeful, prosperous, and just economy where every member of society gets the rewards that are due to them. The components of economic justice in an Islamic society are:

First, equal freedom and opportunities for all members of society to utilize natural resources that are available, abundant, and unlimited (Baqir al-Hasani \& Abbas Mirakhor, 1998). Freedom means that people are not held back by others to combine their creative work with resources designed to be utilized by individual members of society following sharia rules. Chances are meaningful situations that allow the individual to try everything. The success or failure of a person's efforts depends on his efforts and abilities. Equality of opportunity must be maintained collectively. Equality of access to resources and equality of opportunity in Islam is based on the view that natural resources are not created by humans but are bestowed by Allah Swt. for all members of society, and because of that, freedom and opportunities to use these resources must be distributed equally to all. people (Iqbal, Zamir; Mirakhor, 2011). Because Islam recognizes that individuals are rational actors, in Islam the main causes of poverty are viewed differently. Scarcity is not considered important in explaining poverty in Islam. The main cause of poverty is the injustice created from corruption, the mal-distribution of wealth and opinions, and the waste that accompanies it (Askari \& Arfaa, 2007).

Second, fairness in transactions. Islam conceptualizes that the rules of transactions in the market include regulation of sources of supply and demand for factors and products that comply with sharia before they enter the market, rules of conduct based on sharia for buyers and sellers, and the process of offering prices that are free from various factors that are prohibited by sharia. The rules relating to offer and demand not only govern the permissibility of products to be asked for and bid on, but also probe deep into this phenomenon. Not all requests for products are considered legitimate, and not all acts of supplying products to the market are permitted. The rules of conduct for individuals in the market are designed to ensure fair dealing. Behaviors such as fraud, manipulation, monopolistic practices, coalitions, and a combination of all types among 


\section{2 | Havis Aravik, Achmad Irwan Hamzani, Nur Khasanah, THE ROLE OF THE STATE IN ............}

sellers and buyers, selling products at substandard prices, dumping, hoarding, and bidding without the intention of buying, are prohibited actions. All forms of behavior that lead to ownership rights without going through the correct work process are prohibited (Iqbal, Zamir; Mirakhor, 2011).

Third, distributive justice is a mechanism in which freedom and equal equity are reconciled without violating each other. Islam considers that poverty and inequality are not caused by scarcity or lack of resources, or due to an unsynchronized mode of production and distribution, but rather the result of waste, luxury, waste, and neglect of payments that belong to the community. Islam does not hesitate to assume that all individuals are connected to a certain standard of living; so fulfilling the rights of the poor is a matter of equality and justice, not a matter of generosity alone (Iqbal, Zamir; Mirakhor, 2011).

\section{The Concept of Riba and Gharar in Islam}

The term usury is closely related to muamalah activities (Sofhian, 2015). The term usury refers to excess, addiction, and surplus, and the verb related to this word means, to increase, multiply, exaggerate, take more than it should be, or carry out the practice of borrowing money with high interest. By focusing on usury on financial transactions, according to sharia, it technically refers to the premium that must be paid by borrowers to those who provide loans together with the principal amount of debt as a condition for borrowing or an extension of the loan period (Iqbal, Zamir; Mirakhor, 2011).

In Arabic, usury is used in the sense of increasing, expanding, swelling, fattening and having fun, and so on (Ahmed, 2013). Riba in English is called usury, which means taking excessive interest on borrowed money, so it tends to lead to exploitation or extortion (Umam, 2018). Meanwhile, interest is the additional amount paid/received from the principal amount according to the agreement due to the period attached (A. Ahmad \& Humayoun, 2011). Thus usury or interest is in principle the same.

Islam strictly prohibits usury (QS al-Rum [30]: 39, al-Nisa' [4]: 160-161, AlBaqarah [2]: 278-279) (A. U. F. Ahmad \& Hassan, 2014) because Islam opposes every form of exploitation and support an economic system aimed at securing broad socio- 
economic justice. Even dealing with usury-based transactions means declaring war with Allah Swt. and His Messenger (QS. Al-Baqarah [2]: 279) (A. Ahmad \& Humayoun, 2011). For this reason, Islam condemns all forms of exploitation, especially injustice, namely where the lender is guaranteed a positive return without considering the risk with the borrower, or in other words, the borrower bears all types of risk. With the consideration that the wealth owned by an individual is a mandate of Allah Swt., just like a person's life, the mandate of wealth is a sacred thing. So if the wealth is taken inappropriately, it means that there is an injustice that tarnishes human sanctity (Iqbal, Zamir; Mirakhor, 2011).

Riba is considered as an increase or excess of principal or, more precisely, a fixed surplus over debt. In modern economic theory, profit is also seen as a surplus or residual value over contractual payments or just the difference between income and costs (Nur, 2008), of course, this is not true in sharia. The existence of usury is also incompatible with the Islamic value system, which prohibits all forms of unjustified wealth seeking. Riba, which represents unequal and therefore unjustified financial gain, is different from trading, which results in an exchange of equal value. By eliminating usury, each party in the contract will get a fair and equal reward, which in turn will lead to an equal distribution of income and then to a more equitable economic system (Iqbal, Zamir; Mirakhor, 2011).

Riba is against the nature of human life on earth, creates conflict, and destroys cooperation. Riba contradicts the nature of the production environment which is characterized by the uncertainty of yields. Thus, all contracts and financial transactions as certain forms of contracts - must comply with sharia principles and only apply if they do not contain usury (Rahman, 2017), uncertainty (gharar), gambling (maisir), and prohibited activities (non-halal) (Johanna Pesendorfer, 2016). Broadly speaking, usury can live latently or potently in a discriminatory, exploitative, and predatory economic system which means that it can live in a subordinated, capitalistic, neoliberalism, and hegemonic imperialistic economic system (Kalsum, 2014). 


\section{4 | Havis Aravik, Achmad Irwan Hamzani, Nur Khasanah, THE ROLE OF THE STATE IN ............}

Most people still wonder whether interest and usury are both included in the category of usury. Given that there are fundamental differences between usury and interest. Usury emphasizes taking excessive profits on borrowing money, while interest according to some people is normal, to maintain the value of a currency (Umam, 2018). Answering this question Abbas Mirakhor stated that in the aspect of interest, riba is not justified because interest is a property that is claimed outside the framework of legal individual property rights recognized by Islam and is instant.

After all, as soon as the loan agreement based on interest is included, the lender's right to the borrower's property has been created, regardless of the results of the effort for which the money was used. Of course, this action is against Islamic principles. AlQur'an clearly and strictly prohibits the acquisition of the property of others through improper means (Surah Al-Baqarah [2]: 188, An-Nisa [4]: 29, An-Nisa [4]: 161 and AtTaubah [9]: 34). Interest as a resource that can be invested is not efficient because it is allocated not according to productivity but according to the creditworthiness of the borrower. So the concept of usury is more than just a prohibition to collect interest, it is also prohibited from making more than what is given (Rahman, 2017).

In modern times, towards the mid-1980s, economic and financial theories have shown that there are weaknesses in contracts in interest-based banking. Among them: First, these contracts or covenants create inefficient defaults on financial liabilities or assets. Second, because the information is asymmetrical, money covenants contain a moral hazard effect and a poor selection effect. Third, the fixed cost agreement creates a fundamental conflict between the interests of the lender and the borrower. Fourth, the social sector with low profitability will not be financed, new entrepreneurs who have good projects may not receive funds because they do not have the required securities (Iqbal, Zamir; Mirakhor, 2011). So interest has become the economic hallmark of the dominant western civilization, while Islamic civilization in its heyday functioned based on profit sharing and trade credit. The rejection of interests is an important step towards the economic revival of Muslims (Rahman, 2017).

Many Muslim scholars claim that Islam's prohibition of usury has two dimensions; the first dimension is to present business and commercial contracts with an 
equal share of risk, and the second, consider the act of making a loan as an act of virtue on the grounds of helping someone in need. If a person needs capital for commercial purposes, it must be provided on a risk-sharing basis and if someone needs funds to cover short-term needs, that need should not be exploited and the borrower should not be burdened with burdensome conditions.

Sharia regards borrowers as duty-free contracts, encourages Muslims to offer social loans (qard al-hasan), and condemns the accumulation of wealth for the sake of accumulating wealth. Providing loans without usury is considered a generous act that deserves a blessing; on the other hand, lending money with usury has very long consequences (QS. Al-Hadid [57]: 11 and al-Taghaabun [64]: 17). Even the Surah alRum [30]: 39 offers an interesting proposition which states that the act of charity, including lending without interest is more valuable in the eyes of Allah Swt., compared to wealth through usury (interest). According to the existing tradition, Rasulullah Saw. said; Riba seems beautiful but the result is scarcity and contention. On another occasion, the Prophet said: boasting with usury brings a people to destruction (HR. Imam Ahmad) (Iqbal \& Mirakhor, 2012). From these various verses, the al-Qur'an has clear instructions regarding business and trading activities because income from trade (Bai) is lawful but interest-based activities (Riba) are haram. Banking activities are part of economic activity and Islam only allows usury-free banking (A. Ahmad \& Humayoun, 2011).

As an alternative to the interest system in conventional economies, Islamic economics offers a profit and loss sharing system when the owner of capital (surplus spending unit) cooperates with entrepreneurs (deficit spending unit) to carry out business activities. If the business activities generate profits, the profits are shared and if the business activities suffer losses, the losses are also shared. This profit-sharing system can take the form of mudharabah or musyarakah with various variations (Budiantoro et al., 2018).

Meanwhile, gharar is the most important element in a financial contract. In simple terms, gharar comes from problems related to information and refers to the uncertainty 


\section{Havis Aravik, Achmad Irwan Hamzani, Nur Khasanah, THE ROLE OF THE STATE IN ............}

created by a lack of information and knowledge about the outcome of the contract or the nature and quality of the subject matter or lack of control in the contract (Uddin, 2015). Gharar is considered as neglect of essential elements in a transaction, such as the exact selling price or the seller's willingness to provide what is being sold, and so on. The existence of gharar in the contract makes the contract null and void (Iqbal, Zamir; Mirakhor, 2011).

Gharar is interpreted as a situation where there is a contracted party who has no information regarding the articles in the contract, which are held by the other party, and/or the contract article is something that cannot be controlled by either party. For example, buying and selling transactions of birds or fish that have not been caught, calves that are still in their mother's stomach, and animals that have escaped and have not been caught, and so on. All of these cases involved selling items whose existence was a possibility. Another example is when the subject of a sale and purchase is not owned by one of the parties and there is uncertainty about its ownership in the future (Iqbal, Zamir; Mirakhor, 2011). The prohibition of gharar refers to surah al-Baqarah [2]: 188, al-Nisa [4]: 29, al-Baqarah [2]: 219 and al-Maidah [5]: 93) (Uddin, 2015).

Gharar forms are all uncertainties of quantity, quality, ability to return, or the existence of goods that are the subject of the contract, all of which are contrary to sharia (Aravik, 2020). By viewing gharar as excessive uncertainty, one can negotiate gharar with an element of risk. The ban on gharar will force the parties to avoid contracts that are not informed, and this prohibition will make the transacting parties more responsible and accountable. However, becoming gharar as a risk has consequences, namely the prohibition of trading in gharar. The prohibition of trading in gharar is considered a risk prohibition or prohibition of derivative instruments in today's financial markets, which are designed to transfer risk from one party to another. One of the implications of the ban on gharar is the prohibition of pure speculation and gambling activities, which contain asymmetric information, excessive uncertainty, extreme risk, and lack of control (Iqbal, Zamir; Mirakhor, 2011). In conventional insurance, the premiums paid by policyholders and the compensation provided by the insurer for a claim are equally 
uncertain, thus making conventional insurance feasible from the perspective of Islamic law (Uddin, 2015).

\section{The Role of the State in Islamic Economics}

Islam considers economic relations and behavior as a way of integrating society into a higher level of reality. To this end, one is required to view one's economic attainment as a means, not an end. All rules of conduct relating to economic matters are addressed to individuals and groups. This group is organized into a form of government, which is represented by the state. The state is considered a basic institution that must exist to organize social life, to create material and spiritual prosperity, and to maintain and spread faith (Iqbal, Zamir; Mirakhor, 2011). With a basic function as stated by Ibn Khaldun that makes everyone follow sharia in their life (Mulyana, 2017).

The state must be present in the form of carrying out an ideal justice system as the implementation of duties and responsibilities in the way of Allah, without discriminating even against itself or its people (Adnan Abd Rashid \& Arifin Mamat, 2013). Because the state is the party that has the authority to lay the foundations of regulations that support and protect economic growth and activity (Hidayatullah, 2015). Meanwhile, the essential purpose of an established country is to provide maslahah to all of its people without exception. Maslahah should be able to deliver all members of society to prosperity in this world and the hereafter (Mahtum, 2019).

The most important role of the state is closely related to the Islamic political economy (Zakiyah, 2017). In addition, the role of the state is a derivation of the concept of the caliphate and the consequence of collective obligations (fard al-kifayah) to realize falah. The state is the holder of the mandate of Allah and His Messenger as well as the mandate of the community to carry out collective tasks in creating welfare and (al-adl wah ihsan) for all people. In general, the role of this state will be related to realizing an Islamic market concept and realizing the goals of the Islamic economy as a whole (Sulistyowati, 2017). 


\section{8 | Havis Aravik, Achmad Irwan Hamzani, Nur Khasanah, THE ROLE OF THE STATE IN ............}

According to Abbas Mirakhor, the role of the state in the Islamic economy is; First, ensuring all people have equal access to natural resources and ways of earning a living. Second, ensure that every individual has equal opportunities to get education, skills, and technology and the opportunity to take advantage of all these resources. Third, ensure the market is properly monitored so that fairness in exchange can be achieved. As is the practice of Rasulullah Saw., he often conducts inspections to the market to check prices and market mechanisms so that there are no actions that are contrary to sharia values. Fourth, ensure the transfer of wealth from the rich to the poor following sharia rules. Fifth, ensure fair distribution of the next generation through the implementation of inheritance rules.

To maximize these roles, the state is given the right to design specific economic policies to achieve all these goals. To finance the expenses needed to carry out its duties, the state through sharia regulations is given the authority to control, use and manage some natural resources, for example, mining. Sharia also allows the state to collect taxes if there is a gap between revenue from resources and government spending. Even the state is allowed to go into debt, as long as it does not involve interest and in an emergency arena (Iqbal, Zamir; Mirakhor, 2011).

Thus, the state has the highest authority and role to eliminate inequality and disparity in society caused by various unhealthy economic practices such as hoarding, monopoly, oligopoly, and fraud. As expected by Ibnu Khaldun, the role of the state as a facilitator of human development and welfare (Zakiyah, 2017). Therefore, the weakness of state intervention in a liberal-capitalist economy has brought several accesses and negative consequences. Starting from the level of unequal income, increasing poverty, and widening social disparities. This happens, a market that works optimally makes competition inevitable, entrepreneurs with the large capital beat and displace small entrepreneurs. Capital and wealth revolve around only a handful of people.

In contrast, in a socialist system, inequality, poverty, and income distribution can be overcome. However, the competition system is prohibited, the drive for achievement and increasing productivity tends to be absent. As a result, this system failed to promote significant economic growth. So in an Islamic economic perspective, the role of the 
state must contribute to ensuring the creation of conditions that support the mechanism of economic activity to run fairly, and encourage the birth of morality which is adorned with an attitude of honesty, openness, and justice to produce healthy competition, not as the liberal-capitalist concept or socialist-communists.

\section{Conclusions}

From the discussion above about the problems raised, it can be concluded that Abbas Mirakhor is one of the important figures in Islamic economics, including a reformer in the Islamic economy and a follower of the Iqtishad School. Abbas Mirakhor's offer in Islamic economics is seen in the use of a hermeneutic approach as a solution in comprehensive research and study of the Islamic economic system. In the context of the role of the state, Mirakhor requires the state to be present in the form of implementing an ideal justice system. Because the role of the state is closely related to the Islamic political economy. Therefore, the state must ensure that all people have equal access to natural resources and earn a living, the state must ensure that every individual has equality in all matters, the state must ensure a market that is free of manipulation and control, and ensure the transfer of wealth from the rich to the poor as well as the distribution of justice that lasts for the next generation 


\section{REFERENCE}

Adnan Abd Rashid, \& Arifin Mamat. (2013). Educational View of the Islamic Leadership: Are the Islamic Leaders Performing Their Responsibilities? International Journal of Humanities and Social Science, 3(3), 178-185.

Ahmad, A., \& Humayoun, A. A. (2011). Islamic banking and prohibition of Riba/interest. African Journal of Business Management, 5(5), 1763-1767. https://doi.org/10.5897/AJBM10.723

Ahmad, A. U. F., \& Hassan, M. K. (2014). Riba and Islamic Banking Abu Umar Faruq Ahmad, University of Western Sydney. Journal of Islamic Economics, Banking and Finance, March.

Ahmed, F. A. S. M. F. M. A. R. (2013). Critical Analysis Of Islamic Concept Of Interest. International Journal of Asian Social Science, 3(5), 1260-1267.

Aravik, H. (2017). Pemikiran Ekonomi Islam Kontemporer. Jakarta: Kencana.

Aravik, H. \& F. Zamzam (2020). Sejarah Pemikiran Ekonomi Islam Klasik, Palembang: Rafah Press.

Aravik, H. \& F. Zamzam (2020). Filsafat Ekonomi Islam; Ikhtiar Menyelami Nilai Esensial Ekonomi Islam, Jakarta: Kencana.

Askari, H., \& Arfaa, N. (2007). Social safety net in Islam: The case of Persian Gulf oil exporters. British Journal of Middle Eastern Studies, 34(2), 177-202. https://doi.org/10.1080/13530190701427925

Baqir al-Hasani \& Abbas Mirakhor. (1998). Essays on Iqtishad: The Islamic Approach to Economic Problems. Nur.

Borhan, J. T. Bin, \& Sa'ari, C. Z. B. (2002). Economic Functions Of The State: An Islamic Perspective. Jurnal Usuluddin, 16, 75-90.

Budiantoro, R. A., Sasmita, R. N., \& Widiastuti, T. (2018). Sistem Ekonomi (Islam) dan Pelarangan Riba dalam Perspektif Historis. Jurnal Ilmiah Ekonomi Islam, 4(01), 1. https://doi.org/10.29040/jiei.v4i1.138

Haneef, M. A. (2005). Can There Be an Economic Based on Religion? The Case of Islamic Economics. Post-Autistic Economics Review, 34(3), 41-52. http://www.peacon.net/PAEReview/issue34/Garnett34.htm.

Hidayatullah, I. (2015). Peran Pemerintah di Bidang Perekonomian Dalam Islam. Dinar, 1(2), 77-89.

Iqbal, Zamir; Mirakhor, A. (2011). An Introduction to Islamic Finance: Theory and Practice. John Wiley \& Sons.

Iqbal, Z., \& Mirakhor, A. (2012). Financial Inclusion: Islamic Finance Perspective. Journal of Islamic Business and Management, 2(1), 35-64. 
https://doi.org/10.12816/0004974

Johanna Pesendorfer, O. L. (2016). Islamic Banking and Finance As an Ethical Alternative: a Systematic Literature Review. ACRN Oxford Journal of Finance and Risk Perspectives, 5(2), 42-64. https://doi.org/10.31235/osf.io/jb5z9

Kalsum, U. (2014). Riba dan Bunga Bank dalam Islam; Analisis Hukum dan Dampaknya Terhadap Perekonomian Umat. Jurnal Al-'Adl, 7(2), 67-83. U Kalsum - Al-'Adl, 2014 - ejournal.iainkendari.ac.id

Mahtum, A. (2019). Intervensi Negara Dalam Ekonomi Ahmad. Statistical Field Theor, 53(9), 1689-1699. http://ejurnal.unisda.ac.id/index.php/adilla/article/download/732/408/

Mirakhor, A. (2007). A Note on Islamic Economics. Islamic Research and Training Institute.

Mulyana, R. A. (2017). Peran Negara Untuk Mewujudkan Kesejahteraan Dalam Kerangka Maqashidus Syariah. Al-Urban: Jurnal Ekonomi Syariah Dan Filsantropi Islam, 1(2), 155-176. https://doi.org/10.22236/alurban

Nur, E. (2008). Riba Versus Profit in An Exchange Economy: Conceptual Foundations for Stable Financial System in Islamic Perspectives. 7th International Conference on Islamic Economics And. http://www.kantakji.com/media/163535/file541.pdf

Rahman, F. N. (2017). Theory of Islamic Financial System and Economic growth. Journal of Creative Writing, 3(1), 66-82. http://jocw.discinternational.org/index.php/jocw/article/view/42/46

Sofhian. (2015). The Rationality Prohibition Of Riba (Usury). Al-Ulum, 15(1), 237266. http://journal.iaingorontalo.ac.id/index.php/au

Sulistyowati, S. (2017). Rancang Bangun Dan Nilai Dasar Universal Ekonomi Islam. Istithmar: Jurnal Pengembangan Ekonomi Islam, 1(2). https://doi.org/10.30762/itr.v1i2.946

Uddin, M. A. (2015). Principle of Islamic Finance: Prohibition of Riba, Gharar and Mysir. Munich Personal RePEc Archive, 67711, 1-8. https://mpra.ub.unimuenchen.de/67711/1/MPRA_paper_67711.pdf

Umam, K. (2018). Pelarangan Riba Dan Penerapan Prinsip Syariah Dalam Sistem Hukum Perbankan Di Indonesiaumam, K. (2018). Pelarangan Riba Dan Penerapan Prinsip Syariah Dalam Sistem Hukum Perbankan Di Indonesia. Mimbar Hukum Fakultas Hukum Universitas Gadjah Mada, 29(3), . Mimbar Hukum - Fakultas Hukum Universitas Gadjah Mada, 29(3), 391. https://jurnal.ugm.ac.id/jmh/article/view/28436 
22 | Havis Aravik, Achmad Irwan Hamzani, Nur Khasanah, THE ROLE OF THE STATE IN ............

Wilber, C. K. (2003). Ethics in Economic Theory. Post-Autistic Economics Review, 20(1). http://www.peacon.net/PAEReview/issue20/Wilber20.htm.

Zakiyah, K. (2017). Peran Negara Dalam Distribusi Kekayaan (Perspektif Ekonomi Islam). Al-Falah: Journal of Islamic Economics, 2(1), 37. https://doi.org/10.29240/jie.v2i1.88 